\title{
Effect of Ripening in Brine and in a Vacuum on Protein, Fatty Acid and Mineral Profiles, and Antioxidant Potential of Reduced-Fat White Cheese
}

\author{
Miroljub Barać ${ }^{*} \odot$, Zlatan \\ Sarić® Tanja Vučić ${ }^{\circledR}$, \\ Ivana Sredović Ignjatović', \\ Danijel Milinčić ${ }^{\oplus}$, Bojana \\ Špirović Trifunović ${ }^{1}$ \\ and Milenko Smiljanić3 \\ 'University of Belgrade, Faculty \\ of Agriculture, Nemanjina 6, \\ 11080 Zemun, Serbia \\ ${ }^{2}$ University of Sarajevo, Faculty of \\ Agriculture and Food Sciences, \\ Zmaja od Bosne 8, 71000 Sarajevo, \\ Bosnia and Herzegovina \\ 3University of East Sarajevo, \\ Faculty of Technology, \\ Karakaj 34A, 75400 Zvornik, \\ Bosnia and Herzegovina
}

Received: 9 July 2020

Accepted: 10 February 2021

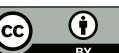

\footnotetext{
*Corresponding author:

Phone: +381114413268

E-mail: baracm@agrif.bg.ac.rs
}

\begin{abstract}
SUMMARY
Research background. Numerous factors affect the ripening of reduced-fat white cheese. The aim of this study is to investigate the influence of ripening environment (brine or vacuum plastic bags without brine) on the chemical composition, protein, fatty acid profile and mineral content as well as antioxidant properties of industrially produced reduced-fat white cheese.

Experimental approach. A low-fat white cheese was manufactured on an industrial scale from milk that remained after the production of kajmak and ripened for 60 days at $4{ }^{\circ} \mathrm{C}$ after packaging in a polystyrene container with brine containing $6 \%$ salt or in vacuum-sealed polyethylene bags. The influence of ripening environment on proteolysis was monitored by the change of soluble nitrogen fractions as well as by sodium dodecyl sulphate-polyacrylamide gel electrophoresis of Tris(hydroxymethyl) aminomethane- $\mathrm{HCl}$ extracts of cheese proteins under non-reducing conditions and water-soluble fractions under reducing conditions. An effect that ripening environment had on fatty acid and mineral content was also monitored. The change of antioxidant potential of the investigated cheese during ripening led to the change of iron(II) chelating ability, reducing power and free-radical scavenging activity.

Results and conclusions. The ripening environment differently affected proteolysis, fatty acid composition, mineral profile and antioxidant properties of reduced-fat white cheese. White cheese ripened in brine had more intensive proteolytic changes than the cheese ripened in a vacuum, but also more intensive diffusion processes, especially between the 40th and 60th day of ripening. The brine-ripened cheese had higher values of water-soluble nitrogen content, but lower contents of trichloroacetic acid-soluble and phosphotungstic acid-soluble nitrogen than the vacuum-ripened cheese. Cheese ripened in brine had a lower content of almost all investigated macro- and microelements. After 60 days of ripening, in cheese ripened in brine only myristic (C14:0) and palmitic acid (C16:0) were detected, whereas in the vacuum-ripened cheese C10:0-C16:0 fatty acids dominated. Vacuum-ripened reduced-fat cheese had more favourable reducing power, while white brined reduced-fat cheese had better radical scavenging activity and iron(II) chelating activity.

Novelty and scientific contribution. These results suggest significant influence of ripening conditions (immersion in brine or in vacuum-sealed polyethylene bags) on nutritive and functional properties of reduced-fat white cheese. Ripening in a vacuum has become a useful method for obtaining high-value reduced-fat white cheese.
\end{abstract}

Key words: reduced-fat white cheese, proteolysis, fatty acids, mineral profile, antioxidant properties

\section{INTRODUCTION}

In recent years, there has been increased interest in the industrial production of kajmak, a traditional product of Southeast European countries that can be described as a skin-like layer that forms during cooling of previously high-heat treated milk. The production of kajmak is based on the aggregation of milk fat and the inclusion of a part of milk 
proteins. Milk that remains after the kajmak production is used mainly for the production of reduced- or low-fat white brined cheese. However, residual milk has specific properties that can affect cheese characteristics. Residual milk is characterized by a low content of fat and fat-soluble substances, as well as slightly lower protein content than the raw milk. The low fat content of milk can affect the composition, ripening biochemistry, microstructure, organoleptic/sensory characteristics and yield of the cheese (1). In addition, during the production of kajmak, milk is subjected to more severe thermal processing (at $90^{\circ} \mathrm{C}$ for up to $60 \mathrm{~min}$ ) than typical pasteurization and slow cooling (up to $24 \mathrm{~h}$ ). It is known that high-heat treatment induces whey protein denaturation, especially a-lactalbumin ( $\alpha$-La) and $\beta$-lactoglobulin $(\beta-L g)$ and the formation of whey protein-casein complexes (2). The presence of high amount of these complexes increases the rennet clotting time of milk, whereas the incorporation of micellar whey protein-casein complexes into the cheese curd reduces syneresis, increases water-binding ability (3) and affects proteolysis (4). Furthermore, a long period of milk fat separation provides proteolytic activity of thermostable enzyme plasmin and activity of bacteria that originate from the environment. This may additionally affect the coagulation of milk and the cheese ripening process.

White cheese made from milk that remains after the production of kajmak is usually ripened and marketed in brine, while in well-organized dairy plants after ripening in brine cheese is vacuum packaged in polyethylene bags and then distributed. Ripening in brine can negatively affect the nutritional value of reduced-fat white cheese. Due to the diffusion processes that occur in brine, these types of cheese can lose part of the nitrogenous substances, macro- and microelements and can have a relatively high $\mathrm{NaCl}$ content. Thus, from a practical and hygienic aspect, ripening without brine in vacuum-sealed plastic bags could be more convenient. Besides the low fat content, cheese ripened in a vacuum would also have a low level of salt and would be suitable for those who avoid consuming white cheese because of its high salt content. Furthermore, ripening in a vacuum instead of brine would avoid the loss of a part of low-molecular-mass peptides. Since these peptides are mainly responsible for cheese bioactivity, this could contribute to higher nutritive value. Finally, vacuum-sealed package is more hygienic, it prolongs the shelf-life and makes this type of cheese more suitable for large-scale market distribution and broader consumption than the traditionally ripened in brine.

Although the biochemistry of ripening of different reduced-fat cheese varieties was the topic of several studies $(1,5-8)$, to the best of the authors' knowledge, there are no studies related to the ripening of reduced-fat white cheese made from milk that remains after kajmak production. Also, there is no study about the effect of ripening in a vacuum on the composition and properties of reduced-fat white cheese.

This study aims to compare the effect of ripening in brine or vacuum plastic bags without brine on the chemical composition, protein and fatty acid profiles, mineral content, as well as antioxidant properties of industrially produced reduced-fat white cheese. This can contribute to a better understanding of the ripening of reduced-fat cheese. Also, the obtained results can contribute to the modification of existing technologies in the development of reduced-fat cheese with higher nutritional value.

\section{MATERIALS AND METHODS}

\section{Cheese making}

The Serbian reduced-fat white cheese samples were manufactured on an industrial scale in a local dairy Spasojevic d.o.o (Bajina Basta, Serbia), from cow's milk that remained after the production of kajmak using a kajmak production device patented by Marković and Maćej (9). Cheese was made on three consecutive days in three replicates. The average content of fat and protein of the raw milk used was 3.88 and $3.66 \%$, respectively, and the average $\mathrm{pH}$ was 6.64 . The pretreatment of the milk and the protocol for the reduced-fat cheese production are shown in Fig. S1. The average content of fat and protein of the residual milk was 1.07 and $3.37 \%$, respectively, and the average $\mathrm{pH}$ was 6.10 . The milk was tempered at $32-33^{\circ} \mathrm{C}$ and commercial starter culture methotrexate washed cells (MTX WC; Dalton Biotecnologie, Spoltore, Italy) was added. The composition of the starter culture was: Lactococcus lactis ssp. lactis, Lactococcus lactis ssp. cremoris, Streptococcus salivarius ssp. thermophilus, Lactobacillus delbrueckii ssp. bulgaricus and Lactobacillus helveticus. After $1 \mathrm{~h}$, $\mathrm{CaCl}_{2}$ (200 mg/L, as $20 \%$ solution) and commercial rennet (90 mg/L; Maxiren, DSM Food Specialties BV, Delft City, The Netherlands) were added. Curd was formed within $45 \mathrm{~min}$ at $32-33^{\circ} \mathrm{C}$. Next, the curd was cut crossways in cubes of $1 \mathrm{~cm}^{3}$ and tempered at $37-38^{\circ} \mathrm{C}$ for about $40 \mathrm{~min}$. Then, it was gently agitated for $15 \mathrm{~min}$ to facilitate whey expulsion and carefully transferred into the mould $(80 \mathrm{~cm} \times 50 \mathrm{~cm} \times 20 \mathrm{~cm})$. After that, the curd was left for $30 \mathrm{~min}$ to settle under the pressure of its own weight, and then pressed for $1 \mathrm{~h}$ at $50 \mathrm{kPa}$ and another hour at $100 \mathrm{kPa}$. After that, the cheese curd was cut into pieces of $10 \mathrm{~cm} \times 10 \mathrm{~cm} \times 4 \mathrm{~cm}$, dry salted with $w(\mathrm{NaCl})=3.0 \%$ and left overnight. The next day, half of the cheese slices of each batch were placed into plastic containers $(30 \mathrm{~cm} \times 25 \mathrm{~cm} \times$ $15 \mathrm{~cm})$, covered with $w(\mathrm{NaCl})=6 \%$ brine and closed with a lid. The other half of the slices was packed (each slice individually) into vacuum-sealed plastic bags. The cheese samples were ripened at $4{ }^{\circ} \mathrm{C}$ for 3 days in a dairy plant, transported to the laboratory and then stored for 60 days at the same temperature and $70 \%$ humidity in the ripening room. The cheese was sampled at 3, 20, 40 and 60 days of ripening.

\section{Chemical analysis}

Prior to analysis, the cheese samples (whole slices) were ground to achieve uniformity. The chemical composition of the cheese samples was determined using the following 
methods: dry matter by the standard drying method at $(102 \pm 2)^{\circ} \mathrm{C}(10)$, fat content according to the gravimetric method (11), nitrogen content by the AOAC method (12) and $\mathrm{NaCl}$ content by the Volhard method (13). The protein content was calculated as the nitrogen content multiplied by nitrogen conversion factor 6.38. Using these parameters fat and protein in dry matter, moisture in non-fat solids and salt in moisture were calculated and expressed as mass fraction in \%. The $\mathrm{pH}$ of the cheese samples was measured using a $\mathrm{pH}$ meter (Consort, Tumhout, Belgium) (14).

\section{Proteolysis assessment}

Proteolysis was monitored by measuring the contents of water-soluble nitrogen, $12 \%$ trichloroacetic acid-soluble nitrogen and $5 \%$ phosphotungstic acid-soluble nitrogen according to Kuchroo and Fox (15). These parameters were expressed as a percentage of total nitrogen. Besides these parameters, sodium dodecyl sulphate-polyacrylamide gel electrophoresis (SDS-PAGE) of Tris(hydroxymethyl) aminomethane- $\mathrm{HCl}$ (Tris- $\mathrm{HCl}$ ) extracts of cheese proteins under non-reducing conditions and water-soluble fractions under reducing conditions, according to the Fling and Gregerson method (16) was done. Electrophoresis was performed on $5 \%$ $(\mathrm{m} / \mathrm{V})$ stacking and $12.5 \%(\mathrm{~m} / \mathrm{V})$ resolving gel (gel electrophoresis apparatus model LKB-2001; LKB, Uppsala, Sweden). The water-soluble fraction was extracted as described by Kuchroo and Fox (15), and diluted with Tris-HCl buffer (0.055 M Tris- $\mathrm{HCl}, \mathrm{pH}=6.8,2 \%$ SDS, $5 \% \beta$-mercaptoethanol (V/V), $7 \%$ glycerol, $0.0025 \%$ bromophenol blue). Tris- $\mathrm{HCl}$ extracts of cheese proteins were prepared using the same buffer but without $\beta$-mercaptoethanol. After filtration, the cheese extracts were diluted to $2 \mathrm{mg} / \mathrm{mL}$. Low-molecular-mass calibration kit (Pharmacia, Uppsala, Sweden) was used to estimate molecular masses of the polypeptides in water-soluble fraction. A mixture of the major milk proteins $\left(\alpha_{s}-, \beta\right.$ - and $k$-casein, a-lactalbumin and $\beta$-lactoglobulin; Sigma-Aldrich, Merck, St Louis, MO, USA) prepared under the same non-reducing conditions was used for identification of cheese protein bands. The scanned gels were analyzed by SigmaGel software v. 1.1 (17). Caseins and polypeptides were quantitatively determined by integration of peak signals. Intensity of casein bands was quantified from the gel on which $25 \mu \mathrm{L}$ of the samples were applied. Each pattern was analyzed in triplicate. Residual content of identified caseins was expressed as a mass fraction of their initial mass in 3-day-old cheese.

\section{Analysis of fatty acids}

Prior to fatty acid and mineral content analyses, the cheese samples were frozen at $-80^{\circ} \mathrm{C}$ and lyophilized (at $-44{ }^{\circ} \mathrm{C}$ and $9.7 \mathrm{~Pa}$ overnight) using Labconco freeze dryer (Labconco Corp., Kansas City, MO, USA). The lipid compounds were extracted from lyophilized cheese samples using hexane and transferred into fatty acid methyl esters (FAMEs) as we reported in our previous study (18). FAMEs were separated using capillary gas chromatography with flame ionization detector (model 6890; Agilent Technologies, Santa Clara, CA, USA) equipped with split/splitless injector and SP-2560 (length $100 \mathrm{~m}$, i.d. $0.25 \mathrm{~mm}$, film thickness $0.20 \mu \mathrm{m}$; Supelco, Bellefonte, PA, USA). The obtained chromatographic peaks were identified using Supelco 37 Component FAME mix standard. Fatty acid content was calculated in $\mathrm{mg} / \mathrm{g}$ lipids and expressed as mass fraction (in \%) of total fatty acids.

\section{Mineral profile}

Lyophilized cheese samples were digested in a microwave digestion system (microwave oven Berghof, Speedwave, Berghof, Germany) using concentrated nitric acid and hydrogen peroxide. Macroelements ( $\mathrm{Ca}, \mathrm{Mg}, \mathrm{Na}$ and $\mathrm{K}$ ) were determined by flame atomic absorption spectroscopy (200 Series AA; Agilent Technologies, Inc.), whereas the microelements ( $\mathrm{Fe}, \mathrm{Zn}, \mathrm{Cu}$ and $\mathrm{Mn}$ ) were determined by inductively coupled plasma-mass spectrometry (ICP-MS model iCAP Q; Thermo Scientific, Oxford, UK). A multi-element stock solution XXI for MS (MES-21-5; AccuStandard, New Haven, CT, USA) containing $10 \mu \mathrm{g} / \mathrm{mL}$ of each element was used for the preparation of working standard solutions for the ICP-MS measurements by serial dilutions. Individual single-element stock solutions containing $1000 \mathrm{mg} / \mathrm{L} \mathrm{Ca}, \mathrm{Mg}$, Na and K were supplied by AccuStandard. Murphy-Riley method, a dry ashing colourimetric method (19), was used to determine the content of phosphorus. This method is based on the interaction between phosphorus and ammonium molybdate and formation of blue phosphomolybdate complexes. The absorbance was measured at $700 \mathrm{~nm}$ using Shimadzu 1900i spectrophotometer (Shimadzu Corporation, Kyoto, Japan). The mass fraction of phosphorus in cheese was calculated using standard calibration curve for phosphorus, and expressed in $\mathrm{mg} / 100 \mathrm{~g}$.

\section{Antioxidant properties of cheese}

The iron(II) chelating ability and the reducing power of cheese were measured and expressed as previously described in detail (4). The chelating activity was calculated as follows:

$$
\text { Chelating activity }=\left(1-\frac{A(\text { sample })}{A(\text { control })}\right) \cdot 100
$$

The reducing power of cheese was expressed as the absorbance of the reaction mixture measured at $700 \mathrm{~nm}$. A higher absorbance indicates a greater reducing power.

Free radical scavenging activity was evaluated using a previously published method (20). Briefly, the stock solution (7 mM aqueous solution of ABTS (2,2-azino-bis(3-ethyl benothiazoline-6-sulphonic acid) with $2.45 \mathrm{mM}$ potassium persulfate) was allowed to stand in the dark for $16 \mathrm{~h}$. The working solution of ABTS was prepared by diluting the stock solution with methanol to obtain an absorbance between 0.7 and 0.8 at $734 \mathrm{~nm}$. Thereafter, $10 \mathrm{mg}$ of cheese were mixed with $1 \mathrm{~mL}$ of ABTS working solution and intensively stirred. After $7 \mathrm{~min}$, samples were centrifuged for $5 \mathrm{~min}$ at $17000 \times \mathrm{g}$, and the 
absorbance of the supernatants was measured at $734 \mathrm{~nm}$. Percentage of quenched radicals for standard and samples was calculated as:

$$
\mathrm{ABTS}^{+} \text {scavenging activity }=\left(\frac{A_{\mathrm{c}}-A_{\mathrm{s}}}{A_{\mathrm{c}}}\right) \cdot 100
$$

where $A_{c}$ is the absorbance of ABTS working solution, $A_{s}$ is the absorbance of sample or standard solution mixed with ABTS working solution. Butylated hydroxytoluene (BHT) solutions ranging from 10 to $100 \mu \mathrm{g} / \mathrm{mL}$ were used to prepare a calibration curve. The free radical scavenging activity was expressed as the percentage of inhibition as well as the BHT equivalent in $\mu \mathrm{g} / \mathrm{mL}$.

\section{Statistical analysis}

Data were subjected to one-way analysis of variance (ANOVA) with IBM-SPSS v. 20 software (21). The analyses were performed in duplicate at each sampling time for each cheese variant. All measurements were performed in triplicate. Mean values were compared with Tukey's test at $p<0.05$. Interactions between variables were evaluated and interpreted via linear correlation coefficients using Pearson's correlation.

\section{RESULTS AND DISCUSSION}

\section{Compositional analysis}

Table 1 shows the chemical composition of the cheese samples analyzed during 60 days of ripening. Dry matter and protein in dry matter (PDM) mass fractions were significantly $(p<0.05)$ lower in cheese ripened in brine than in the cheese samples ripened in a vacuum. This can be attributed to the water absorption from the brine, especially during the first days of the second stage of ripening in the cold storage because: (i) at low temperature the casein-bound calcium tends to be soluble, thus increasing casein hydration, (ii) the peptides coming from proteolysis bind water (22), and (iii) the heat-induced incorporation of hydrophilic whey proteins which increases the ability of a cheese matrix to bind water tightly (23).
The lower values of PDM in cheese samples treated in brine than in vacuum are probably the result of the diffusion of low-molecular-mass nitrogen compounds which formed during ripening in brine. In fact, dry matter and protein content in the cheese samples in brine decreased throughout the 60 -day ripening. Thus, strong negative correlations between the time of ripening and dry matter $(-0.941, \mathrm{p}<0.05)$ as well as between the time of ripening and protein content $(-0.993$, $p<0.05$ ) in these samples were found. This agrees well with the increase of moisture content in non-fat solids (MNFS) (Table 1). The most intensive decrease of dry matter mass fraction was observed between $40-60$ days of ripening. It seems that this period of ripening is crucial for biochemical and sensory characteristics of reduced-fat cheese ripened in brine. In contrast to the cheese in brine, no significant $(p<0.05)$ changes of dry matter, PDM and MNFS were found within 60 days in the cheese ripened in vacuum-sealed plastic bags.

From the results presented in Table 1, it is evident that cheese in brine had significantly $(p<0.05)$ higher values of MNFS than vacuum-sealed cheese. Namely, MNFS of cheese in brine during ripening increased continually from 68.08 to $79.53 \%$, whereas no significant changes were noticed in the vacuum-sealed cheese. Since a small mass fraction increase in MNFS (2-4\%) leads to a relatively large increase in the available water, which in turn leads to increases in the activity of enzymes and microorganisms (24), a higher level of proteolytic products in brined than in vacuum-sealed cheese can be expected.

Reduced-fat cheese generally had similar fat in dry matter (FDM) content (Table 1). The only exception was the cheese ripened for 60 days in brine due to the decrease of PDM mass fraction between 40 and 60 days. Based on the results in Table 1, a significantly higher $\mathrm{pH}$ value of brined than of vacuum-sealed cheese was observed. This agrees with the $\mathrm{NaCl}$ and salt in moisture content in the cheese (Table 1). It seems that the $\mathrm{pH}$ of both cheese types intensively decreased after the first three days of ripening and then became almost constant. In fact, after an initial decrease the $\mathrm{pH}$ of vacuum-sealed cheese was constant after 20 days and then slightly but significantly $(\mathrm{p}<0.05)$ decreased, whereas the $\mathrm{pH}$ of the

Table 1. The chemical composition and $\mathrm{pH}$ of reduced-fat white cheese

\begin{tabular}{|c|c|c|c|c|c|c|c|c|}
\hline \multirow{2}{*}{$\begin{array}{c}t \text { (ripening)/ } \\
\text { day }\end{array}$} & $w(\mathrm{DM}) / \%$ & $w(\mathrm{FDM}) /(\%)$ & $w(\mathrm{PDM}) / \%$ & $w(\mathrm{MNFS}) / \%$ & $\mathrm{pH}$ & $w(\mathrm{NaCl})_{\text {cheese }} / \%$ & $w(\mathrm{NaCl})_{\text {moisture }} / \%$ & Acidity $/{ }^{\circ} \mathrm{SH}$ \\
\hline & \multicolumn{8}{|c|}{ Cheese ripened in a vacuum } \\
\hline 3 & $(43.0 \pm 0.7)^{\mathrm{a}}$ & $(29.1 \pm 0.6)^{\mathrm{b}, c}$ & $(55.4 \pm 0.6)^{\mathrm{a}}$ & $(65.2 \pm 0.7)^{\mathrm{e}}$ & $(5.06 \pm 0.01)^{c}$ & $(1.56 \pm 0.04)^{d}$ & $2.66^{\mathrm{e}}$ & $(82.9 \pm 0.6)^{d}$ \\
\hline 20 & $(42.5 \pm 0.7)^{\mathrm{a}}$ & $(30.0 \pm 0.7)^{\mathrm{b}}$ & $(55.9 \pm 0.7)^{\mathrm{a}}$ & $(65.9 \pm 0.6)^{\mathrm{e}}$ & $(5.05 \pm 0.00)^{c}$ & $(1.67 \pm 0.04)^{c}$ & $2.82^{d}$ & $(90.3 \pm 0.5)^{c}$ \\
\hline 40 & $(41.1 \pm 0.6)^{\mathrm{a}}$ & $(28.3 \pm 0.9)^{\mathrm{b}, \mathrm{c}}$ & $(54.4 \pm 1.0)^{\mathrm{a}, \mathrm{b}}$ & $(66.7 \pm 0.4)^{\mathrm{e}}$ & $(4.96 \pm 0.00)^{d}$ & $(1.62 \pm 0.05)^{c}$ & $2.67^{e}$ & $(95.3 \pm 0.3)^{\mathrm{b}}$ \\
\hline \multirow[t]{2}{*}{60} & $(41.5 \pm 0.3)^{\mathrm{a}}$ & $(28.9 \pm 1.6)^{\mathrm{b}, \mathrm{c}}$ & $(55.6 \pm 0.7)^{\mathrm{a}}$ & $(66.5 \pm 1.1)^{\mathrm{e}}$ & $(4.97 \pm 0.00)^{d}$ & $(1.53 \pm 0.04)^{d}$ & $2.61^{\mathrm{e}}$ & $(98.8 \pm 0.3)^{\mathrm{a}}$ \\
\hline & \multicolumn{8}{|c|}{ Cheese ripened in brine } \\
\hline 3 & $(39.2 \pm 0.3)^{b}$ & $(27.4 \pm 0.9)^{c}$ & $(53.9 \pm 0.4)^{\mathrm{b}}$ & $(68.1 \pm 0.3)^{d}$ & $(5.42 \pm 0.00)^{\mathrm{a}}$ & $(2.30 \pm 0.06)^{b}$ & $3.65^{\mathrm{b}}$ & $(75.5 \pm 0.5)^{f}$ \\
\hline 20 & $(37.7 \pm 0.2)^{c}$ & $(27.9 \pm 0.8)^{c}$ & $(52.5 \pm 0.4)^{c}$ & $(69.6 \pm 0.5)^{c}$ & $(5.33 \pm 0.02)^{\mathrm{b}}$ & $(2.47 \pm 0.15)^{a, b}$ & $3.81^{\mathrm{a}}$ & $(78.8 \pm 0.6)^{\mathrm{e}}$ \\
\hline 40 & $(35.68 \pm 0.08)^{d}$ & $(29.43 \pm 0.07)^{b}$ & $(51.2 \pm 0.2)^{d}$ & $(71.87 \pm 0.09)^{\mathrm{b}}$ & $(5.34 \pm 0.02)^{b}$ & $(2.54 \pm 0.04)^{\mathrm{a}}$ & $3.80^{\mathrm{a}}$ & $(70.5 \pm 0.2)^{9}$ \\
\hline 60 & $(28.0 \pm 0.1)^{\mathrm{e}}$ & $(33.9 \pm 0.1)^{\mathrm{a}}$ & $(48.8 \pm 0.4)^{\mathrm{e}}$ & $(79.5 \pm 0.1)^{\mathrm{a}}$ & $(5.37 \pm 0.0)^{\mathrm{b}}$ & $(2.39 \pm 0.02)^{\mathrm{b}}$ & $3.21^{c}$ & $(50.5 \pm 0.3)^{\mathrm{h}}$ \\
\hline
\end{tabular}

$\mathrm{DM}=$ dry matter, $\mathrm{FDM}=$ fat in dry matter, $\mathrm{MNFS}=$ moisture in non-fat solid, $\mathrm{PDM}=$ protein in dry matter. Data within the same column marked with different lowercase letters are significantly different at $p<0.05$ 
brined cheese was reduced during the first 20 days and then became constant. The observed changes in the $\mathrm{pH}$ values of vacuum-sealed cheese are in agreement with increasing acidity of these types of cheese. On the contrary, the acidity of brined cheese increased during the first 20 days, and then significantly $(p<0.05)$ decreased. This can be explained as follows: changes in cheese $\mathrm{pH}$ during ripening are determined by the balance of the production of different organic acids (mainly lactic acid) that causes a drop in the $\mathrm{pH}$ and the buffering capacity of the cheese that resists this change in $\mathrm{pH}$ (25). Buffering capacity in cheese is related to proteins and inorganic constituents (weak acids, bases and metal ion complexes), especially inorganic $\mathrm{P}$ and $\mathrm{Ca}$, which are not covalently attached to casein but are entrapped by the para-casein network (26). It can be assumed that proteolysis and ripening at low temperature $\left(4^{\circ} \mathrm{C}\right)$ induce the increase of these forms of $\mathrm{Ca}$ and $\mathrm{P}$. Also, proteolysis occurred during the pretreatment of milk, the primary stage and the first 3 days of ripening inducing liberation of new amino and carboxylic groups which additionally contribute to high buffering capacity of cheese. Due to these facts, the retention of lactic acid increases the acidity but does not affect $\mathrm{pH}$ changes. The acidity of brined cheese started to decrease after 20 days when diffusion of low-molecular-mass compounds including nitrogen compounds, lactic and other organic acid occurred.

As expected, the vacuum-sealed cheese had a much lower salt mass fraction than the brined cheese. Regardless, both types can be considered as reduced-salt white cheese types since the observed values were lower than the values for Serbian white cheese types (3.48-5.43\%) reported by Barać et al. (18).

\section{Nitrogen fractions and protein profiles}

Table 2 shows the change of nitrogen mass fractions of white cheese during ripening and Fig. 1 the results of electrophoresis.

Table 2. The ripening parameters of white cheese ripened in brine or in a vacuum

\begin{tabular}{|c|c|c|c|}
\hline \multirow{2}{*}{$\begin{array}{c}t \text { (ripening)/ } \\
\text { day }\end{array}$} & $\begin{array}{l}(m(\mathrm{WSN}) / \\
m(\mathrm{TN})) / \%\end{array}$ & $\begin{array}{c}(m(\mathrm{PTA}) / \\
m(\mathrm{TN})) / \%\end{array}$ & $\begin{array}{l}(m(\mathrm{TCA}) / \\
m(\mathrm{TN})) / \%\end{array}$ \\
\hline & \multicolumn{3}{|c|}{ Cheese ripened in a vacuum } \\
\hline 3 & $(5.07 \pm 0.09)^{\mathrm{g}}$ & $(0.64 \pm 0.01)^{c}$ & $(4.5 \pm 0.2)^{f, g}$ \\
\hline 20 & $(8.67 \pm 0.06)^{f}$ & $(0.64 \pm 0.03)^{c}$ & $(6.09 \pm 0.02)^{c}$ \\
\hline 40 & $(13.23 \pm 0.08)^{d}$ & $(0.77 \pm 0.01)^{\mathrm{b}}$ & $(7.02 \pm 0.01)^{b}$ \\
\hline \multirow[t]{2}{*}{60} & $(14.5 \pm 0.2)^{c}$ & $(0.96 \pm 0.02)^{\mathrm{a}}$ & $(8.08 \pm 0.02)^{\mathrm{a}}$ \\
\hline & \multicolumn{3}{|c|}{ Cheese ripened in brine } \\
\hline 3 & $(10.3 \pm 0.5)^{\mathrm{e}}$ & $(0.49 \pm 0.03)^{d}$ & $(4.4 \pm 0.1)^{g}$ \\
\hline 20 & $(14.9 \pm 0.1)^{c}$ & $(0.50 \pm 0.01)^{d}$ & $(4.58 \pm 0.02)^{f}$ \\
\hline 40 & $(20.18 \pm 0.04)^{b}$ & $(0.49 \pm 0.02)^{\mathrm{d}}$ & $(5.14 \pm 0.01)^{\mathrm{e}}$ \\
\hline 60 & $(22.9 \pm 0.6)^{\mathrm{a}}$ & $(0.78 \pm 0.03)^{\mathrm{b}}$ & $(5.87 \pm 0.01)^{d}$ \\
\hline
\end{tabular}

$m(\mathrm{WSN}) / m(\mathrm{TN})=$ mass of water-soluble nitrogen in the mass of total nitrogen, $m(\mathrm{PTA}) / m(\mathrm{TN})=$ mass of nitrogen soluble in $5 \%$ phosphotungistic acid in the mass of total nitrogen, $m(\mathrm{TCA}) / m(\mathrm{NT})=$ mass of nitrogen soluble in $12 \%$ trichloracetic acid in the mass of total nitrogen. Data within the same column marked with different lowercase letters are significantly different at $p<0.05$
The 3-day-old (fresh) cheese had significantly different mass fractions (in total nitrogen mass) of water-soluble nitrogen (WSN) and of nitrogen soluble in $5 \%$ phosphotungistic acid (PTA) and similar mass fractions of nitrogen soluble in 12 $\%$ trichloroacetic acid (TCA) (Table 2). In fact, 3-day-old brined cheese had an almost 2-fold higher WSN mass fraction but significantly lower PTA mass fraction than their counterparts ripened in a vacuum.

The presence of soluble nitrogen fractions in fresh cheese could be a result of several processes, including those occurring during pretreatment of milk (thermolysis induced by high-heat treatment and possible proteolysis during $24 \mathrm{~h}$ of kajmak separation), proteolysis during curd processing and during the initial 3 days of ripening. As the cheese samples are prepared from the same pretreated milk and according to an identical procedure, the differences observed in the soluble nitrogen compounds of 3-day-old cheese samples appear to be due to the choice of ripening environment and diffusion occurring in brined cheese. The WSN mass fraction is usually used as an index of cheese ripening and the higher values suggest more intensive initial proteolysis in brined cheese. The water soluble nitrogen mainly consists of the whey proteins, proteose-peptone, low-molecular-mass peptides derived from casein hydrolysis, free amino acids and weakly bound caseins (27). Since 3-day-old (fresh) cheese had low level of phosphotungstic acid (PTA)-soluble nitrogenous substances $(0.49$ and $0.64 \%$ in brine and vacuum respectively), which reflect the content of free amino acids and small peptides (molecular mass lower than $600 \mathrm{Da}$ ), and similar values of the low-molecular-mass peptides (<15 $000 \mathrm{Da}$ ), which are the major compounds of TCA-soluble nitrogenous substances (14), the higher WSN mass fraction in 3-day-old brined cheese can be attributed to the higher content of peptides with molecular mass higher than $15000 \mathrm{Da}$. This observation was confirmed by SDS-PAGE analysis of WSN in 3-day-old cheese samples (Fig. 1b). The SDS-PAGE profile of 3-day-old brined cheese had more intensive bands of high-molecular-mass peptides (18-28 kDa), which are mainly products of residual rennet and residual heat-stable indigenous milk proteinases (26).

As expected, the mass fractions of soluble nitrogen (WSN, TCA and PTA) increased during ripening, but to different extents and with different trends. The WSN of both types of cheese increased continually and rapidly throughout the 60 days (Table 2) and reached a maximum of $14.54 \%$ (vacuum-sealed) and $22.88 \%$ (brined). These values are in accordance with those of 60-day-ripened (matured) low-fat white brined cheese (10-24\%) reported by Romeih et al. (28). In contrast to WSN, the mass fractions of TCA and PTA increased at a much slower rate. In fact, in vacuum-sealed cheese, the TCA increased throughout the 60 days, whereas the increase of PTA was observed after 20 days. On the other hand, in the brined cheese, the increased values of TCA and PTA were observed after 3 and 40 days, respectively (Table 2). Relatively low mass fractions of TCA- and PTA-soluble nitrogen in both 
a)

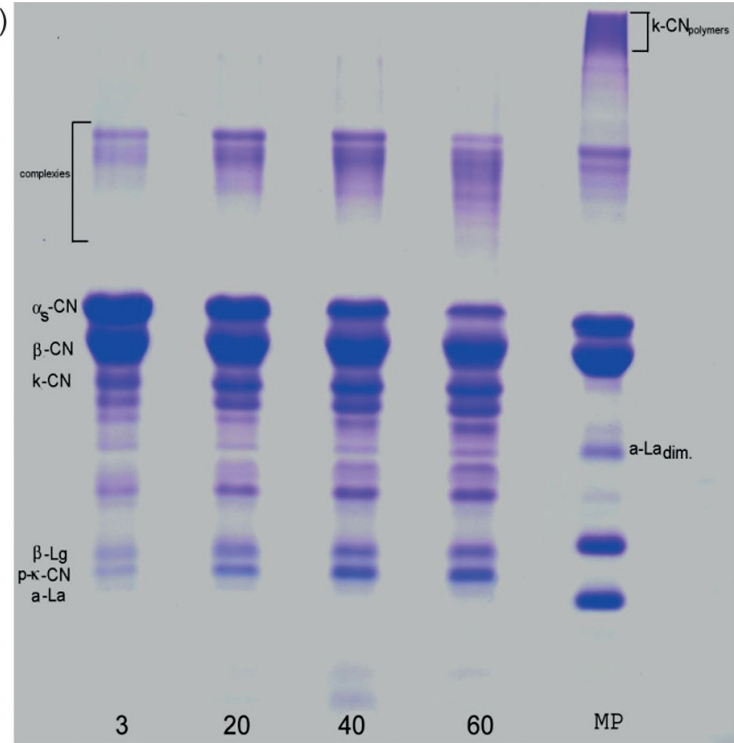

b)

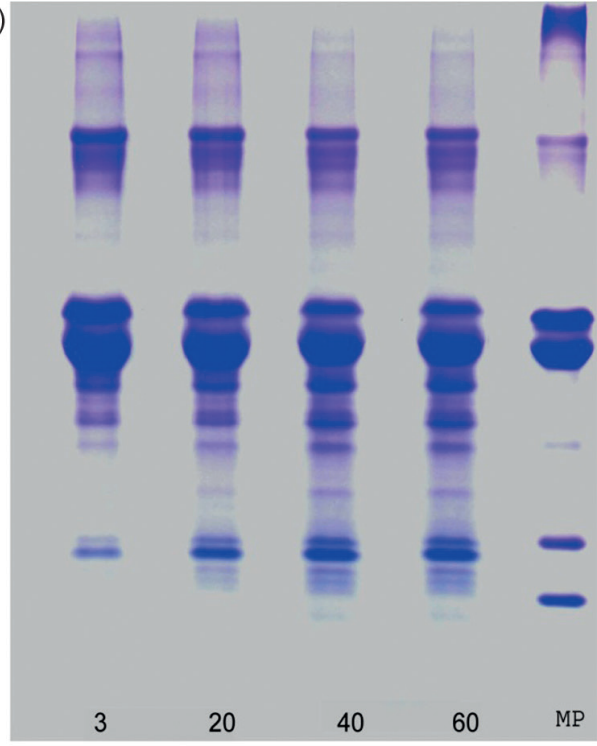

c)

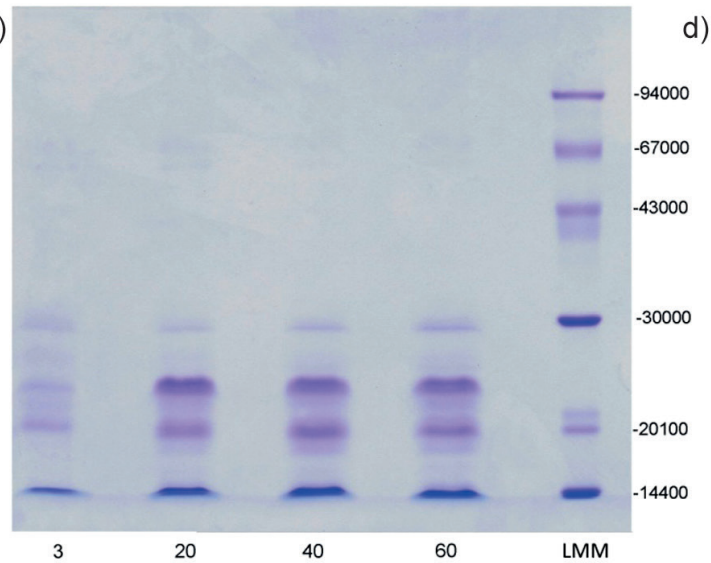

d)

)

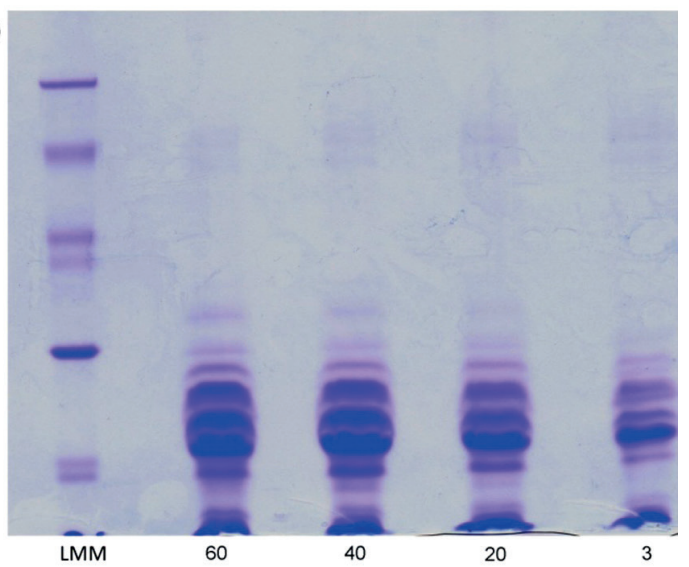

Fig. 1. SDS-PAGE of: $a$ and b) proteins of cheese ripened for 3, 20, 40 and 60 days in brine and vacuum, respectively, under non-reducing conditions, and $\mathrm{c}$ and d) of water-soluble fractions of cheese ripened for 3,20, 40 and 60 days in brine and vacuum, respectively, under reducing conditions. $\mathrm{MP}=$ milk proteins, $\mathrm{CN}=$ casein, $\mathrm{La}=$ lactalbumin, $\mathrm{Lg}=$ lactoglobulin, $\mathrm{La}$ dim $=$ dimmer of lactalbumin, $\mathrm{LMM}=$ low molecular mass standard

60-day-old cheese types suggested slow proteolytic activity of starter and non-starter bacteria, probably due to low ripening temperature $\left(4^{\circ} \mathrm{C}\right)$ and the presence of heat-induced complexes less accessible to enzymes (29). Furthermore, the lower mass fraction of TCA- and PTA-soluble nitrogen in brined than in vacuum-sealed cheese can indicate slightly slower bacterial activity, which agrees with higher salt mass fraction in brined cheese (Table 1). Since salt mass fraction lower than $2.5 \%$ had no adverse effect on bacterial activity in the cheese (30), the lower mass fractions of low-molecular-mass nitrogen substances (TCA and PTA) in brined cheese should be attributed to their diffusion into brine rather than to slower bacterial activity. This is supported with the significant $(p<0.05)$ decrease of dry matter content in the brined cheese and strong negative correlation $(-0.955,-0.971$; $\mathrm{p}<0.05$ ) among TCA, PTA and dry matter content.

According to Fig. 1b, ripening conditions significantly affected SDS profiles of water-soluble peptides of both types of cheese. Ripening in brine at low temperature $\left(4^{\circ} \mathrm{C}\right)$ promotes the increase of the high- and medium-size molecular mass peptides (18-28 kDa). Besides these peptides, less intensive casein bands of $\alpha_{s}-C N, \beta-C N$ and trace amount of polypeptides with molecular mass between 62 and $73 \mathrm{kDa}$ could be observed. It is known that at a low temperature, due to the reduction in hydrophobic interactions, the dissociation of $\beta$-casein, and, to a lesser extent, dissociation of other individual caseins from the micellar structure occurred (31). In contrast to the brined cheese, in the WSN fractions of vacuum-sealed cheese only a band of $\beta-C N$ was observed, which increased during ripening, while most of the detectable peptides were those with molecular mass of 14, 21 and $26 \mathrm{kDa}$ (Fig. 1b). This suggested slower primary proteolysis in vacuum-sealed cheese, probably due to lower moisture and MNFS content and due to the lower $\mathrm{pH}$, which is less favourable for plasmin activity than values detected in brined cheese (Table 1).

Hydrolysis of $a_{s}$ - and $\beta$-casein was expressed as a mass fraction (in \%) of the corresponding mass of casein present 
on the third day of ripening (Table 3). As can be seen, the residual $a_{s}$ - and $\beta$-caseins in both cheese types continuously decreased during ripening. The rate of hydrolysis of the two caseins was different. In both cheese types the proteolysis of $a_{s}$-casein was faster and more extensive than that of $\beta$-casein. This is attributed to the structure of the $\beta$-casein, which renders the molecule less accessible to enzymes (32). Also, it was shown that severe heat treatment additionally slows down $\beta$-casein degradation slightly and increases the rate of hydrolysis of $a_{s}$-caseins (33), making these differences more pronounced. The breakdown of both caseins was significantly $(p<0.05)$ faster in brined than in vacuum-sealed cheese. After 60 days, the residual $a_{s}-$ and $\beta$-casein in the brined cheese were 20.31 and $82.26 \%$, respectively. At the same time, the residual $a_{s}$ - and $\beta$-casein in the vacuum-sealed cheese were about 65 and $92 \%$, respectively (Table 3 ). The more extensive degradation of $\beta$-casein observed in brined than in vacuum-sealed cheese could be attributed to higher $\mathrm{pH}$ values in the brined cheese, which would enhance the activity of the indigenous milk proteinases (34).

It is interesting to note that the most intensive degradation of $\mathrm{a}_{\mathrm{s}}$-casein in brined cheese was between the 40th and 60 th day of ripening. During this period residual $a_{s}$-casein declined from 61.08 to $20.31 \%$ of the $a_{s}$-caseins present in the 3 -day-old cheese. Since in this period also the most intensive loss of dry matter and protein in dry matter occurred ( $\mathrm{Ta}$ ble 1), it could be attributed mainly to the diffusion of

Table 3. The change of residual $a_{s}$-casein and $\beta$-casein during ripening of white cheese in brine and in a vacuum

\begin{tabular}{|c|c|c|c|c|}
\hline \multirow{4}{*}{ Casein type } & \multicolumn{4}{|c|}{$t$ (ripening)/day } \\
\hline & 3 & 20 & 40 & 60 \\
\hline & \multicolumn{4}{|c|}{$w($ residual casein) $/ \%$} \\
\hline & \multicolumn{4}{|c|}{ Cheese ripened in brine } \\
\hline$a_{5}-C N$ & 100 & 77.41 & 61.08 & 20.31 \\
\hline \multirow[t]{2}{*}{$\beta-C N$} & 100 & 94.25 & 91.01 & 82.26 \\
\hline & \multicolumn{4}{|c|}{ Cheese ripened in a vacuum } \\
\hline$a_{s}-C N$ & 100 & 73.59 & 66.06 & 64.95 \\
\hline$\beta-C N$ & 100 & 96.71 & 94.82 & 92.07 \\
\hline
\end{tabular}

The mass fractions of residual $a_{s}-C N$ and $\beta-C N$ in ripened cheese were expressed as percentage of the mass fraction present in the extracts of 3-day-old cheese $\mathrm{a}_{\mathrm{s}}$-casein degradation products. This was completely consistent with the results of Romeih et al. (28).

The results presented in Fig. 1 and Table 2 clearly indicate higher proteolysis in the brined than vacuum-sealed cheese, mainly due to more intensive primary proteolysis. Our results contradict those of Hayaloglu et al. (35) and Miloradovic et al. (36), who reported a higher proteolysis in the cheese ripened in a vacuum. Besides the different treatment of the milk, the observed disagreements could be attributed to the initial ripening period, during which the intensive processes, including proteolysis and diffusion in low-fat cheese occurred (28). Namely, in both reported studies, cheese was initially ripened (first 10 days) in brine and then transferred into vacuum plastic bags. In this study, after dry salting, cheese samples were continually ripened from the first day in brine or in a vacuum.

\section{Macro- and microelement profiles}

Table 4 shows the mass fractions $(\mathrm{g} / 100 \mathrm{~g})$ of macro- (Ca, $\mathrm{K}, \mathrm{Mg}, \mathrm{P}$ and $\mathrm{Na}$ ), and microelements ( $\mathrm{Fe}, \mathrm{Zn}, \mathrm{Cu}$ and $\mathrm{Mn}$ ) in the samples of reduced-fat cheese. Their contents in both cheese types were comparable with those in low-fat white brined cheese reported by Jaoude et al. (37). Contrary to previously reported data for Serbian full-fat white brined types of cheese (18) under the conditions used in this study, the presence of $\mathrm{Pb}, \mathrm{Cd}, \mathrm{Li}, \mathrm{B}, \mathrm{Cr}, \mathrm{Al}$ and $\mathrm{Ni}$ was not detected. In both types of cheese $\mathrm{Na}, \mathrm{Ca}$ and $\mathrm{P}$ dominated, whereas the most represented microelements were $Z n$ and Fe. In general, ripening conditions differently affected the mass fractions of $\mathrm{Ca}, \mathrm{P}, \mathrm{Na}$ and $\mathrm{Mg}$, whereas there was no significant influence on the mass fraction of K. Due to the dissolution of casein-bound $\mathrm{Ca}$ and $\mathrm{P}$ induced at low ripening temperature and their diffusion from the aqueous phase of cheese into the brine their mass fraction started to decrease from the 20 days of ripening. This phenomenon results in intensive binding of water if a small amount of sodium chloride is present, especially at $\mathrm{pH}=5.2-5.4$ (22). This is in good agreement with the results reported in Table 1.

The correlation analysis showed strong negative correlations $(-0.977$ and $-0.952 ; \mathrm{p}<0.05)$ between the time of ripening in brine and the mass fractions of $\mathrm{Ca}$ and $\mathrm{P}$. Also, in these cheese samples a strong positive correlation $(0.984 ; \mathrm{p}<0.05)$

Table 4. The change of the mass fraction in lyophilized cheese of macro- and microelements during cheese ripening in brine and in a vacuum

\begin{tabular}{|c|c|c|c|c|c|c|c|c|c|c|}
\hline \multirow{2}{*}{ Cheese } & \multirow{2}{*}{ t/day } & \multicolumn{5}{|c|}{$w /(\mathrm{mg} / 100 \mathrm{~g})$} & \multicolumn{4}{|c|}{$w /(\mu \mathrm{g} / 100 \mathrm{~g})$} \\
\hline & & $\mathrm{Ca}$ & $\mathrm{Mg}$ & $\mathrm{Na}$ & $\mathrm{K}$ & $\mathrm{P}$ & $\mathrm{Fe}$ & $\mathrm{Cu}$ & $\mathrm{Zn}$ & $M n$ \\
\hline \multirow{4}{*}{$\begin{array}{l}\text { Ripened } \\
\text { in a } \\
\text { vacuum }\end{array}$} & 3 & $(679 \pm 9)^{a}$ & $(25.1 \pm 0.5)^{b}$ & $(953 \pm 65)^{c}$ & $(123 \pm 10)^{\mathrm{a}}$ & $(424 \pm 15)^{\mathrm{a}}$ & $(358 \pm 11)^{a}$ & $(61.5 \pm 6.4)^{\mathrm{a}}$ & $(2409 \pm 48)^{d}$ & $(14.0 \pm 0.5)^{b}$ \\
\hline & 20 & $(682 \pm 6)^{a}$ & $(25.0 \pm 1.1)^{\mathrm{b}}$ & $(1111 \pm 97)^{\mathrm{b}, \mathrm{c}}$ & $(134 \pm 5)^{a}$ & $(415 \pm 6)^{a}$ & $(355 \pm 14)^{a}$ & $(59.4 \pm 6.5)^{\mathrm{a}}$ & $(2227 \pm 62)^{f}$ & $(9.8 \pm 0.6)^{c}$ \\
\hline & 40 & $(674 \pm 6)^{a}$ & $(24.6 \pm 0.5)^{\mathrm{b}}$ & $(1023 \pm 63)^{b, c}$ & $(126 \pm 15)^{\mathrm{a}}$ & $(395 \pm 10)^{a}$ & $(352 \pm 10)^{a}$ & $(69.5 \pm 2.1)^{\mathrm{a}}$ & $(2800 \pm 17)^{\mathrm{b}}$ & $(7.8 \pm 0.2)^{d}$ \\
\hline & 60 & $(684 \pm 11)^{\mathrm{a}}$ & $(23.8 \pm 0.6)^{b}$ & $(958 \pm 44)^{c}$ & $(134 \pm 11)^{\mathrm{a}}$ & $(401 \pm 8)^{a}$ & $(363 \pm 9)^{a}$ & $(67.2 \pm 2.3)^{a}$ & $(3068 \pm 25)^{a}$ & $(9.8 \pm 0.8)^{c}$ \\
\hline \multirow{4}{*}{$\begin{array}{l}\text { Ripened } \\
\text { in brine }\end{array}$} & 3 & $(688 \pm 10)^{\mathrm{a}}$ & $(30.8 \pm 0.4)^{\mathrm{a}}$ & $(1350 \pm 15)^{a}$ & $(125 \pm 2)^{a}$ & $(410 \pm 11)^{\mathrm{a}}$ & $(363 \pm 3)^{\mathrm{a}}$ & $(12.5 \pm 2.5)^{b}$ & $(2605 \pm 16)^{c}$ & $(13.4 \pm 1.0)^{b}$ \\
\hline & 20 & $(680 \pm 17)^{a}$ & $(29.1 \pm 0.3)^{\mathrm{a}}$ & $(1339 \pm 10)^{a}$ & $(130 \pm 14)^{a}$ & $(403 \pm 8)^{a}$ & $(361 \pm 5)^{a}$ & $(12.4 \pm 1.9)^{\mathrm{b}}$ & $(2304 \pm 33)^{e}$ & $(16.5 \pm 0.9)^{\mathrm{a}}$ \\
\hline & 40 & $(626 \pm 15)^{b}$ & $(29.3 \pm 0.2)^{\mathrm{a}}$ & $(1112 \pm 31)^{b}$ & $(126 \pm 14)^{a}$ & $(320 \pm 10)^{b}$ & $(350 \pm 4)^{a}$ & $(14.9 \pm 1.4)^{b}$ & $(2337 \pm 45)^{\mathrm{e}}$ & $(14.2 \pm 0.2)^{b}$ \\
\hline & 60 & $(590 \pm 12)^{c}$ & $(18.1 \pm 0.3)^{c}$ & $(1106 \pm 12)^{b}$ & $(121 \pm 7)^{a}$ & $(300 \pm 3)^{\mathrm{b}}$ & $(292 \pm 8)^{b}$ & $(14.1 \pm 1.7)^{b}$ & $(2287 \pm 30)^{e}$ & $(16.7 \pm 0.6)^{a}$ \\
\hline
\end{tabular}

Data within the same column marked with different lowercase letters are significantly different at $\mathrm{p}<0.05$ 
between the change of $\mathrm{Ca}$ and $\mathrm{P}$ mass fractions was observed. Ripening in brine longer than 40 days also reduced the mass fractions of $\mathrm{Mg}$, Fe and $\mathrm{Mn}$, whereas the mass fraction of $Z n$ decreased after 20 days and then became constant. Contrary to the cheese ripened in brine, ripening in a vacuum had no significant $(p<0.05)$ influence on the mass fractions of almost all detected macro- and microelements. The only exceptions were the mass fractions of $\mathrm{Zn}$ and $\mathrm{Mn}$; after 60 days of ripening the mass fraction of $\mathrm{Zn}$ increased by $27.35 \%$, whereas of $\mathrm{Mn}$ was reduced by approx. $30 \%$ (Table 4). Consequently, no significant correlation between the time of ripening and the mass fractions of individual minerals in this type of cheese was observed.

\section{Fatty acid profiles}

Table 5 shows fatty acid profiles of white cheese ripened in brine and in a vacuum. As could be expected, the method used in kajmak production significantly affected fatty acid profiles of reduced-fat cheese types. Under experimental conditions used in this study, up to eleven fatty acids in 3-day-old brined and vacuum-sealed cheese were detected. Seven of them were saturated (SFA) and four were unsaturated (C4-C16), monounsaturated (MUFA) and polyunsaturated fatty acids (PUFA). As it is evident, fatty acid profiles of 3-day-old cheese samples were similar qualitatively. More precisely, the absence of oleic acid (C18:1n9c) from the brined cheese samples was the only qualitative difference from the 3-day-old vacuum-sealed cheese. However, more pronounced differences in the quantitative composition of fatty acid profiles of these samples is observable. In both 3-day-old cheese types, the SFAs dominated, but their mass fraction was higher (74.48\%) in the 3-day-old reduced-fat brined cheese than in the vacuum-sealed cheese (71.51\%). The most abundant saturated fatty acid in both 3-day-old cheese types was palmitic (C16); its average mass fraction in total fatty acid content of both types of 3-day-old cheese was 51.15 and $43.20 \%$, respectively. The higher mass fraction of palmitic acid observed in the 3-day-old brined cheese samples can be attributed to the significantly lower mass fractions of short-chain (C4-C6) and medium-chain (C8) fatty acids, which represent only $2.64 \%$ of the identified fatty acids. In the vacuum-sealed cheese the mass fraction of these acids was $8.44 \%$. These fatty acids are volatile and much more soluble than the longchain fatty acids (38). Thus, the low mass fractions of C4-C8 fatty acids in the 3-day-old cheese ripened in brine is probably due to the diffusion of their free forms into the brine.

It is interesting to note that the major unsaturated fatty acids of both 3-day-old cheese types were elaidic (C18:1n9t) and linolelaidic (C18:2n6t) acid. The sums of their mass fractions in 3-day-old cheese were almost identical; they represented $24.42 \%$ (brined) and $24.68 \%$ (vacuum-sealed) of detected fatty acids. Both fatty acids are trans-fatty acids naturally present in the milk and cheese but at low amount. However, their mass fractions were higher than those reported for full-fat cheese (18), partly due to the separation of most of the commonly abundant milk fatty acids. Additionally, it is possible that under the heating conditions $\left(90^{\circ} \mathrm{C}\right.$, $60 \mathrm{~min}$ ) used during kajmak production, part of naturally present unsaturated cis-fatty acids (such as oleic acid) are converted into their thermodynamically more stable trans-forms $(39,40)$.

According to the results in Table 5, ripening in brine induces more intensive lipolytic changes than ripening in a vacuum. In cheese ripened in brine for 20 days, only three fatty acids (myristic, palmic and linoleaidic acid) were detected. In contrast, ripening in a vacuum longer than 20 days induces the loss of C4:0-C8:0, C18:1n9 and C18:3n6. Consequently, in the cheese ripened in a vacuum for 60 days, saturated fatty acids $\mathrm{C} 10-\mathrm{C} 16$ dominated.

\section{Antioxidant properties}

The previous sections show that ripening in brine and in a vacuum differently affected protein, fatty acid and mineral

Table 5. Fatty acid profiles of white cheese ripened in brine and in a vacuum

\begin{tabular}{|c|c|c|c|c|c|c|c|c|}
\hline \multirow{4}{*}{ Fatty acid } & \multicolumn{8}{|c|}{$t$ (ripening)/day } \\
\hline & 3 & 20 & 40 & 60 & 3 & 20 & 40 & 60 \\
\hline & \multicolumn{4}{|c|}{ Cheese ripened in a vacuum } & \multicolumn{4}{|c|}{ Cheese ripened in brine } \\
\hline & \multicolumn{8}{|c|}{$w($ fatty acid $) / \%$} \\
\hline C4:0 butyric & $(3.1 \pm 0.1)^{\mathrm{b}}$ & $(4.09 \pm 0.08)^{\mathrm{a}}$ & n.d. & n.d. & $(1.21 \pm 0.04)^{c}$ & n.d. & n.d. & n.d. \\
\hline C6:0 caproic & $(3.22 \pm 0.01)^{\mathrm{b}}$ & $(3.34 \pm 0.03)^{\mathrm{a}}$ & n.d. & n.d. & $(0.92 \pm 0.02)^{c}$ & n.d. & n.d. & n.d. \\
\hline C8:0 caprylic & $(2.10 \pm 0.05)^{\mathrm{a}}$ & $(2.10 \pm 0.04)^{\mathrm{a}}$ & n.d. & n.d. & $(0.51 \pm 0.03)^{b}$ & n.d. & n.d. & n.d. \\
\hline C10:0 capric & $(3.74 \pm 0.01)^{b}$ & $(3.75 \pm 0.05)^{b}$ & $(3.72 \pm 0.06)^{\mathrm{b}}$ & $(4.71 \pm 0.01)^{\mathrm{a}}$ & $(3.35 \pm 0.08)^{c}$ & n.d. & n.d. & n.d. \\
\hline C12:0 lauric & $(3.86 \pm 0.02)^{d}$ & $(4.02 \pm 0.01)^{c}$ & $(4.31 \pm 0.05)^{b}$ & $(4.83 \pm 0.02)^{\mathrm{a}}$ & $(3.94 \pm 0.05)^{c, d}$ & n.d. & n.d. & n.d. \\
\hline C14:0 myristic & $(12.27 \pm 0.08)^{\mathrm{e}}$ & $(12.20 \pm 0.05)^{\mathrm{e}}$ & $(16.70 \pm 0.10)^{b}$ & $(21.9 \pm 0.1)^{\mathrm{a}}$ & $(13.40 \pm 0.09)^{d}$ & $(14.8 \pm 0.5)^{c}$ & $(14.8 \pm 0.3)^{c}$ & $(16.0 \pm 1.0)^{c}$ \\
\hline C16:0 palmitic & $(43.2 \pm 0.1)^{\mathrm{h}}$ & $(41.40 \pm 0.09)^{i}$ & $(44.50 \pm 0.04)^{g}$ & $(43.60 \pm 0.06)^{f}$ & $(51.2 \pm 0.1)^{d}$ & $(65.0 \pm 0.2)^{c}$ & $(66.05 \pm 0.06)^{b}$ & $(66.60 \pm 0.08)^{a}$ \\
\hline C18:1n9c oleic & $(2.20 \pm 0.09)^{\mathrm{a}}$ & $(2.10 \pm 0.05)^{\mathrm{a}}$ & n.d. & n.d. & n.d. & n.d. & n.d. & n.d. \\
\hline C18:1n9t elaidic & $(12.92 \pm 0.07)^{c}$ & $(13.20 \pm 0.01)^{\mathrm{b}}$ & $(16.81 \pm 0.05)^{a}$ & $(12.42 \pm 0.0)^{d}$ & $(12.51 \pm 0.02)^{d}$ & n.d. & n.d. & n.d. \\
\hline C18:2n6t linoleaidic & $(11.76 \pm 0.08)^{e}$ & $(11.7 \pm 0.1)^{\mathrm{e}}$ & $(13.04 \pm 0.03)^{d}$ & $(12.52 \pm 0.04)^{d}$ & $(11.91 \pm 0.09)^{e}$ & $(21.30 \pm 0.05)^{\mathrm{a}}$ & $(19.22 \pm 0.02)^{b}$ & $(17.40 \pm 0.06)^{c}$ \\
\hline C18:3n6 $y$-linoleic & $(1.61 \pm 0.09)^{b}$ & $(2.20 \pm 0.01)^{\mathrm{a}}$ & n.d. & n.d. & $(1.10 \pm 0.08)^{c}$ & n.d. & n.d. & n.d. \\
\hline
\end{tabular}

n.d.=not detected. Data within the same row marked with different lowercase letters are significantly different at $p<0.05$ 
Table 6. The change of antioxidant properties of reduced-fat cheese

\begin{tabular}{|c|c|c|c|c|}
\hline \multirow{2}{*}{$t$ (ripening)/day } & Fe(II) chelating ability/\% & Reducing power $\left(A_{700 \mathrm{~nm}}\right)$ & ABTS inhibition/\% & $\mathrm{ABTS}$ as $\mathrm{BHT} /(\mu \mathrm{g} / \mathrm{mL})$ \\
\hline & \multicolumn{4}{|c|}{ Cheese ripened in a vacuum } \\
\hline 3 & $(25.0 \pm 1.3)^{\mathrm{e}}$ & $(0.372 \pm 0.008)^{\mathrm{a}}$ & $(68.7 \pm 1.2)^{d}$ & $(109.01 \pm 6.1)^{\mathrm{d}, \mathrm{e}}$ \\
\hline 20 & $(33.5 \pm 0.8)^{d}$ & $(0.37 \pm 0.02)^{\mathrm{a}}$ & $(73.7 \pm 1.3)^{c}$ & $(97.6 \pm 6.4)^{\mathrm{e}}$ \\
\hline 40 & $(38.0 \pm 1.5)^{c}$ & $(0.385 \pm 0.007)^{\mathrm{a}}$ & $(86.12 \pm 2.0)^{\mathrm{a}}$ & $(140.7 \pm 3.8)^{a}$ \\
\hline \multirow[t]{2}{*}{60} & $(25.2 \pm 1.0)^{\mathrm{e}}$ & $(0.37 \pm 0.01)^{\mathrm{a}}$ & $(76.9 \pm 1.8)^{c}$ & $(123.0 \pm 3.5)^{c}$ \\
\hline & \multicolumn{4}{|c|}{ Cheese ripened in brine } \\
\hline 3 & $(69.2 \pm 0.5)^{\mathrm{a}}$ & $(0.35 \pm 0.01)^{b}$ & $(66.2 \pm 4.5)^{d}$ & $(102.4 \pm 8.6)^{d, e}$ \\
\hline 20 & $(64.0 \pm 2.2)^{\mathrm{b}}$ & $(0.37 \pm 0.01)^{\mathrm{a}}$ & $(74.4 \pm 2.8)^{c}$ & $(118.1 \pm 5.4)^{c, d}$ \\
\hline 40 & $(65.1 \pm 1.3)^{\mathrm{b}}$ & $(0.40 \pm 0.02)^{\mathrm{a}}$ & $(78.0 \pm 2.8)^{\mathrm{b}, \mathrm{c}}$ & $(125.0 \pm 5.5)^{\mathrm{b}, \mathrm{c}}$ \\
\hline 60 & $(33.8 \pm 1.2)^{d}$ & $(0.261 \pm 0.009)^{c}$ & $(81.3 \pm 0.7)^{\mathrm{b}}$ & $(131.4 \pm 1.3)^{\mathrm{b}}$ \\
\hline
\end{tabular}

$\mathrm{ABTS}=$ radical scavenging capacity, $\mathrm{BHT}=$ butylated hydroxytoluene. Data within the same column marked with different lowercase letters are significantly different at $\mathrm{p}<0.05$

profiles of reduced-fat cheese. It could be assumed that ripening in brine or in a vacuum also had different influence on their antioxidant properties. Therefore, the change of ABTS radical scavenging activity, iron(II) chelating activity and reducing power of the whole cheese during ripening was investigated. The obtained results are in Table 6.

According to Table 6, 3-day-old cheese samples had similar ABTS radical scavenging activity, but significantly different iron(II) chelating activity and reducing power values. In fact, 3-day-old brined cheese had more than twice higher iron(II) chelating activity value and by $7.51 \%$ lower reducing power value than vacuum-sealed cheese. Iron(II) chelating activity of the cheese depends on the presence of aromatic and hydrophobic amino acids (especially the amount of histidine), phosphoserine residues, carboxylate groups (41) and the initial content of $\mathrm{Fe}^{2+}$ and other ions that can also chelate proteins. Since 3-day-old cheese samples had similar initial mass fractions of $\mathrm{Fe}^{2+}$ and macroelements (such as $\mathrm{Ca}, \mathrm{P}$ and Mg) (Table 4), the higher values of iron(II) chelating activity in the brined cheese can be attributed to the more intensive initial proteolysis and more liberated carboxylate groups which can interact with iron ions.

The ripening in brine and in a vacuum differently affected the trend of iron(II) chelating activity and reducing power values. The iron(II) chelating activity of vacuum-sealed cheese increased during 40 days. During the same period, reducing power values of brined cheese slightly but significantly decreased. After that period, the ability of iron(II) chelating dropped sharply in both types of cheese. It reached values equal to those for 3-day-old vacuum-sealed cheese, while the values recorded in brined cheese were almost twice lower than the values of 3-day-old cheese, which is similar to those for 20-day-old vacuum-sealed cheese. The observed decrease of iron(II) chelating activity values agrees well with the previous results reported by Meira et al. (42). These authors suggested that the chelating activity of cheese proteins decreased as the hydrolysis degree increased, probably due to the degradation and/or diffusion of caseinophosphopeptides. This is supported by the loss of phosphorus shown in Table 4.
In contrast to iron(II) chelating activity, throughout 60 days of ripening of vacuum-sealed cheese, no significant changes of reducing power were observed, whereas in the brined cheese, it continually increased during 40 days and then dropped by $34.42 \%$. However, the reducing power of both cheese types was similar or higher than the reducing power of traditional full-fat Serbian white brined cheese (0.156-0.296) reported by Barac et al. (43).

The ripening in brine and in a vacuum had a similar trend of ABTS radical scavenging activity. The radical scavenging activity of both cheese types slowly increased and reached maximum on the 40th day of ripening. After that period, the radical scavenging activity of brined cheese remained unchanged, whereas that of vacuum-sealed cheese decreased. The improved radical scavenging activity of different cheese varieties induced by ripening is documented $(4,42)$ and associated with the increase of low-molecular-mass peptides, free amino acids and proteolytic changes that made the cheese gel network more able to scavenge free radicals. However, the decrease of radical scavenging activity of vacuum-sealed cheese samples observed between 40 and 60 days of ripening suggested that antioxidant peptides were susceptible to further proteolysis.

The correlation analysis showed that besides the time of ripening, the change of ABTS radical scavenging activity was significantly correlated only with water soluble nitrogen in dry matter $(0.979, \mathrm{p}<0.05$; brined cheese) and protein in dry matter (-0.959, $\mathrm{p}<0.05$; vacuum-sealed cheese). The absence of significant correlation between the ABTS radical scavenging activity and other investigated parameters has to be considered as a result of additive, synergistic or antagonistic interactions of caseins, residual whey proteins, peptides and free amino acids released during ripening and minor cheese constituents (such as phenols, vitamins, minerals, etc.) (44).

\section{CONCLUSIONS}

The cheese ripening conditions (immersion in brine or in vacuum-sealed polyethylene bags) affected chemical composition, proteolysis, mineral content, fatty acid composition and antioxidant properties of reduced-fat white cheese 
prepared from the milk that remained after kajmak production. Dry matter, fat and protein contents were higher in the vacuum-ripened than in brined cheese, whereas a higher salt concentration was found in brined cheese. However, more intensive proteolysis was observed in brined cheese, mainly due to the higher degree of degradation of $a_{s}$-caseins. However, due to the absence of diffusion, the cheese ripened in vacuum bags had higher values of parameters related to secondary proteolysis. Also, vacuum-ripened cheese had higher content of $\mathrm{Ca}, \mathrm{P}, \mathrm{Zn}, \mathrm{Fe}$ and $\mathrm{Cu}$ than brined cheese. After 60 days of ripening, myristic (C14:0) and palmitic (C16:0) saturated fatty acid dominated in brined cheese, whereas in vacuum ripened cheese, $\mathrm{C10}: 0-\mathrm{C} 16: 0$ saturated fatty acids remained. Contrary to our predictions, due to more intensive proteolysis, 60-day-old cheese ripened in brine had more favourable ABTS radical scavenging and iron(II) chelating activities, but slightly lower reducing power than vacuum ripened cheese. The results of this study clearly indicate that ripening in a vacuum can be a useful process for obtaining nutritionally highly valuable cheese with reduced milk fat content.

\section{FUNDING}

The present work was funded by the Serbian Ministry of Education, Science and Technological Development (Grant no. 451-0368/2020-14/200116).

\section{CONFLICT OF INTEREST}

The authors have no conflict of interest to declare.

\section{SUPPLEMENTARY MATERIALS}

All supplementary materials are available at: www.ftb. com.hr.

\section{AUTHORS' CONTRIBUTION}

M. Barać participated in the research design, analyzing and interpreting the results and writing the manuscript. $Z$. Sarić was involved in the research design, interpreting of the results and critical revising. T. Vučić was involved in the research design, analyzing the data and experimental analysis. I. Sredović Ignjatović, D. Milinčić, B. Špirović Trifunović and M. Smiljanić did experimental analysis and data analysis.

\section{ORCID ID}

M. Barać @ https://orcid.org/0000-0002-6645-4537

Z. Sarić (i) https://orcid.org/0000-0003-3072-8935

T. Vučić (1) https://orcid.org/0000-0001-6492-9984

B. Špirović Trifunović (i) https://orcid.org/0000-0002-9309-3167

D. Milinčić @i) https://orcid.org/0000-0002-2476-9426

\section{REFERENCES}

1. Moatsou G, Zoidou E, Choundala E, Koutsaris K, Kopsia, O, Thergiaki K, Sakkas L. Development of reduced-fat, reduced-sodium semi-hard sheep milk cheese. Foods. 2019; 8(6):204.

https://doi.org/10.3390/foods8 060204

2. Chevalier F, Kelly AL. Proteomic quantification of disulfide-linked polymers in raw and heated bovine milk. J Agric Food Chem. 2010;58(12):7437-44.

https://doi.org/10.1021/jf1010879

3. Hickey CD, Auty MAE, Wilkinson MG, Sheehan JJ. The influence of cheese manufacture parameters on cheese microstructure, microbial localization and their interactions during ripening: A review. Trends Food Sci Technol. 2015;41(2): 135-48.

https://doi.org/10.1016/j.tifs.2014.10.006

4. Barac M, Pesic M, Zilic S, Smiljanic M, Sredovic Ignjatovic I, Vucic $T$, et al. The influence of milk type on the proteolysis and antioxidant capacity of white-brined cheese manufactured from high-heat-treated milk pretreated with chymosin. Foods. 2019;8(4):128.

https://doi.org/10.3390/foods8040128

5. Moynihan AC, Govindasamy-Lucey S, Jaeggi JJ, Johnson, ME, Lucey JA, McSweeney PLH. Effect of camel chymosin on the texture, functionality, and sensory properties of low-moisture, part-skim mozzarella cheese. J Dairy Sci. 2014;97(1):85-96.

https://doi.org/10.3168/jds.2013-7081

6. Henneberry S, Wilkinson MG, Kilcawley KN, Kelly PM, Guinee TP. Interactive effects of salt and fat reduction on composition, rheology and functional properties of mozzarella-style cheese. Dairy Sci Technol. 2015;95:613-38.

https://doi.org/10.1007/s13594-015-0231-8

7. Soodam K, Ong L, Powell IB, Kentish SE, Gras SL. Effect of rennet on the composition, proteolysis and microstructure of reduced-fat cheddar cheese during ripening. Dairy Sci Technol. 2015;95:665-86. https://doi.org/10.1007/s13594-015-0250-5

8. Schenkel P, Samudrala R, Hinrichs J. The effect of adding whey protein particles as inert filler on thermophysical properties of fat-reduced semi hard cheese type gouda. Int J Dairy Technol. 2013;66(2):220-30.

https://doi.org/10.1111/1471-0307.12036

9. Marković D, Maćej O. Kajmak production device. SRB Patent 55625. 2017 (in Serbian).

10. IDF Standard 4A. Cheese and processed cheese - Determination of the total solids content. Brussels, Belgium: International Dairy Federation; 1982.

11. IDF Standard 5B. Cheese and processed cheese products - Determination of fat content - Gravimetric method. Brussels, Belgium: International Dairy Federation (IDF); 1986.

12. AOAC Official Method 972.43. Microchemical determination of carbon, hydrogen and nitrogen, automated method. Rockville, MD, USA: AOAC International; 1998. 
13. IDF Standard 88A. Cheese and processed cheese products - Determination of chloride content. Brussels, Belgium: International Dairy Federation; 1988.

14. Ardö, Y, Polychroniadou A, European Cooperation in the Field of Scientific and Technical Research (Organization), COST Action 95. Laboratory manual for chemical analysis of cheese. Luxembourg: Office for Official Publications of the European Communities; 1999. pp. 1-144.

15. Kuchroo CN, Fox PF. Soluble nitrogen in Cheddar cheese: Comparison of extraction procedures. Milchwissenschaft. 1982;37(6):331-5.

16. Fling SP, Gregerson DS. Peptide and protein molecular weight determination by electrophoresis using a high-molarity Tris buffer system without urea. Anal Biochem. 1986; 155:83-8.

https://doi.org/10.1016/0003-2697(86)90228-9

17. SigmaGel for Windows, v.1.1, Jandel Scientific, San Rafael, CA, USA; 1994.

18. Barać $M$, Kresojević $M$, Špirović-Trifunović $B$, Pešić $M$, Vučić T, Kostić A, Despotović S. Fatty acid profiles and mineral content of Serbian traditional white brined cheeses. Mljekarstvo. 2018;68(1):37-45.

https://doi.org/10.15567/mljekarstvo.2018.0105

19. Cho YH, Nielsen SS. Phosphorus determination by Murphy-Riley method. In: Nielsen SS, editor. Food analysis laboratory manual. Food science text series. Cham, Switzerland: Springer; 2017. pp. 153-6.

https://doi.org/10.1007/978-3-319-44127-6_17

20. Arnao MB, Cano A, Acosta M. The hydrophilic and hydrophobic contribution to total antioxidant activity. Food Chem. 2001;73(2):239-44. https://doi.org/10.1016/S0308-8146(00)00324-1

21. IBM SPSS, v. 20, IBM Corp., Armonk, NY, USA; 2020. Available from: https://www.ibm.com/products/spss-statistics.

22. Zoidou E, Plakas N, Giannopoulou D, Kotoula M, Moatsou G. Effect of supplementation of brine with calcium on the feta cheese ripening. Int J Dairy Technol. 2015;68(3):420-8. https://doi.org/10.1111/1471-0307.12199

23. Donato L, Guyomarc'h F. Formation and properties of the whey protein/K-casein complexes in heated skim milk - A review. Dairy Sci Technol. 2009;89:3-29. https://doi.org/10.1051/dst:2008033

24. Guinee TP, McSweeney PLH. Significance of milk fat in cheese. In: Fox PF, McSweeney PLH, editors. Advanced dairy chemistry, vol. 2. Lipids. Boston, MA, USA: Springer; 2006. pp. 377-440.

https://doi.org/10.1007/0-387-28813-9_11

25. Hassan A, Johnson E, Lucey J.A. Changes in the proportions of soluble and insoluble calcium during the ripening of Cheddar cheese. J Dairy Sci. 2004;87(4):854-62. https://doi.org/10.3168/jds.S0022-0302(04)73229-4

26. Salum P, Govce G. Kendirci P, Bas D, Erbay Z. Composition, proteolysis, lipolysis, volatile compound profile and sensory characteristics of ripened white cheeses manufactured in different geographical regions of Turkey. Int Dairy J. 2018;87:26-6.

https://doi.org/10.1016/j.idairyj.2018.07.011

27. Mallatou H, Pappa E, Boumba VA. Proteolysis in teleme cheese made from ewes', goats' or a mixture of ewes' and goats' milk. Int Dairy J. 2004;14:977-87.

https://doi.org/10.1016/j.idairyj.2004.03.009

28. Romeih EA, Michaelidou A, Biliaderis CG, Zerfiridis GK. Lowfat white-brined cheese made from bovine milk and two commercial fat mimetics: Chemical, physical and sensory attributes. Int Dairy J. 2002;12:525-40.

https://doi.org/10.1016/S0958-6946(02)00043-2

29. Huppertz T, Upadhyay VK, Kelly AL, Tamime AY. Constituents and properties of milk from different species. In: Tamime A, editor. Brined cheeses. Oxford, UK: Blackwell Publishing; 2006. pp. 1-42.

30. Guven M, Yerlikaya S, Hayaloglu A. Influence of salt concentration on the characteristics of beyaz cheese, a Turkish white-brined cheese. Lait. 2006;86:73-81.

https://doi.org/10.1051/lait:2005043

31. Croguennec $T$, Jeantet $R$, Schuck P. From milk to dairy products. In: Jeantet R, Croguennec T, Schuck P, Brulé G, editors. Handbook of food science and technology, 3: Food biochemistry and technology. London, UK: Wiley \& Sons; 2016. pp. 3-64.

https://doi.org/10.1002/9781119296225.ch1

32. Nega A, Moatsou G. Proteolysis and related enzymatic activities in ten Greek cheese varieties. Dairy Sci Technol. 2012;92:57-73.

https://doi.org/10.1007/s13594-011-0043-4

33. Aydemir O. Proteolysis and lipolysis of white-brined (beyaz) cheese during storage: Effect of milk pasteurization temperature. J Food Process Preserv. 2018;42(5):e13612. https://doi.org/10.1111/jfpp.13612

34. Guinee TP. Role of protein in cheese and cheese products. In: Fox PF, McSweeney PLH, editors. Advanced dairy chemistry, vol. 1: Proteins. New York, USA: Kluwer Academic-Plenum Publishers; 2003. pp.1083-174.

35. Hayaloglu AA, Bansal N, McSweeney P LH. Influence of brine immersion and vacuum packaging on the chemistry, biochemistry, and microstructure of mihalic cheese made using sheep's milk during ripening. Dairy Sci Technol. 2012;92:671-89.

https://doi.org/10.1007/s13594-012-0083-4

36. Miloradovic Z, Kljajevic N, Miocinovic J, Tomic N, Smiljanic J, Macej O. High heat treatment of goat cheese milk. The effect on yield, composition, proteolysis, texture and sensory quality of cheese during ripening. Int Dairy J. 2017;68: $1-8$.

https://doi.org/10.1016/j.idairyj.2016.12.004 
37. Jaoude AD, Olabi A, El Ouyoun Najm N, Malek A, Saadeh C, Baydoun E, Tooufeili I. Chemical composition, mineral content and cholesterol levels of some regular and reduced-fat white brined cheeses and strained yogurt (labneh). Dairy Sci Technol. 2010;90:699-706.

https://doi.org/10.1051/dst/2010026

38. Belitz HD, Grosch W, Schieberle P. Food chemistry. Berlin, Germany: Springer; 2009.

39. Liu W, Lu GH. Cis-trans isomerization of unsaturated fatty acids in edible oils to prepare trans fat. Grasas aceites. 2018; 69(3):268-76.

https://doi.org/10.3989/gya.0225181

40. Tsuzuki W, Matsuoka A, Ushida K. Formation of trans fatty acids in edible oils during the frying and heating process. Food Chem. 2010;123:976-82.

https://doi.org/10.1016/j.foodchem.2010.05.048

41. Pownall TL, Udenigwe CC, Aluko RE. Amino acid composition and antioxidant properties of pea seed (Pisum sativum L.) enzymatic protein hydrolysate fractions. J Agric Food Chem. 2010;58(8):4712-8.

https://doi.org/10.1021/jf904456r

42. Meira SMM, Daroit DJ, Helfer VE, Corrêa APF, Segalin J, Carro S, Brandelli A. Bioactive peptides in water-soluble extracts of ovine cheeses from Southern Brazil and Uruguay. Food Res Int. 2012;48(1):322-9.

https://doi.org/10.1016/j.foodres.2012.05.009

43. Barac M, Vucic T, Zilic, S, Pesic M, Sokovic M, Petrovic J. et al. The effect of in vitro digestion on antioxidant, ACE-inhibitory and antimicrobial potentials of traditional Serbian white-brined cheeses. Foods. 2019;8(3):94.

https://doi.org/10.3390/foods803094

44. Apak R, Ozyurek M, Guclu K, Capanoglu, E. Antioxidant activity/capacity measurement. 1. Classification, physicochemical principles, mechanisms, and electron transfer (ET)-based assays. J Agric Food Chem. 2016;64:9971027.

https://doi.org/10.1021/acs.jafc.5b04739 